1987

\title{
Unitary Taxation in the United States of America
}

Jean-Gabriel Castel

Osgoode Hall Law School of York University, castel@fake.osgoode.yorku.ca

\section{Source Publication:}

Canadian Yearbook of International Law. Volume 25 (1987), p. 369-378.

Follow this and additional works at: https://digitalcommons.osgoode.yorku.ca/scholarly_works

Part of the Tax Law Commons

\section{(c) (1) $9 \odot$}

This work is licensed under a Creative Commons Attribution-Noncommercial-No Derivative Works 4.0 License.

\section{Recommended Citation}

Castel, Jean-Gabriel. "Unitary Taxation in the United States of America." Canadian Yearbook of International Law 25 (1987): 369-378.

This Article is brought to you for free and open access by the Faculty Scholarship at Osgoode Digital Commons. It has been accepted for inclusion in Articles \& Book Chapters by an authorized administrator of Osgoode Digital Commons. 


\section{Unitary Taxation in the United States of America}

$\mathrm{T}$ HE AUTHORITY OF a state to impose taxes on income, property, transfer of wealth, and transactions is an inherent part of its sovereignty. In principle, there is no restraint upon the authority of a state to tax, provided the subject of taxation is jurisdictionally amenable to that state and the tax does not amount to a form of confiscation of property. To be legitimate there must be a territorial or other genuine link between the taxing authority and the person or property taxed. ${ }^{1}$

Taxation of the world income of, or the transfer of wealth by or to, natural or juridical persons on the basis of nationality, domicile, or residence does not violate international law since such taxation is based on actual or constructive presence within the taxing jurisdiction.

A state may also exercise jurisdiction to tax non-national, nondomiciliary, or non-resident natural or juridical persons with respect to income derived from or associated with their presence or their doing business within its territory, or income derived from ownership of property located there. Taxation by a state of property or its transfer which is located within its territory is permissible under international law. The lex situs prevails. Lastly, a state may tax transactions that occur, originate, or terminate within its territory or that have a substantial relation to this state. Here the links with the taxing state are local economic activity or the status of the particular property. In general, states do not always use all these bases of jurisdiction to tax nor have they attempted to tax persons or property that have no connection with their territory whatever.

Usually, when a juridical person has foreign branches or subsidiaries, each is taxed as a separate economic unit on the basis of the income of the entity established within the taxing state. However,

1 D. P. O'Connel, International Law 787-88 (1965), citing George W. Cook (U.S.) v. United Mexican States, IV UNRIAA 593, at 595 (1930). Also see A. R. Albrecht, "The Enforcement of Taxation under International Law;" ( 1953 ) 30 Br. Y.B. Int'l L. 454. 
some states have taxed local parents, affiliates, or subsidiaries under a system of unitary taxation whereby the total world income of the economic unit made of the parent and its affiliated establishments is determined and a portion of it is attributed to the taxing state pursuant to a certain formula.

For instance, in the United States of America a number of states have adopted the unitary business tax for corporations. This tax is not really related to source income, but rather to the reasonable relation to business done in the state. ${ }^{2}$ The unitary tax has been challenged by foreign states on the ground that it is contrary to international law.

The United States government has taken the position that the utilization of the world-wide unitary business concept and apportionment formula method of allocation of income among multinational enterprises engaged in foreign commerce is unconstitutional in that it conflicts with the position the United States has taken with other nations regarding the appropriate standards and methods to be utilized in allocating income among commonly controlled multinational enterprises.

According to the unitary tax concept all the integrated activities of a group of affiliated corporations are combined for tax purposes. Once it is determined that the activities conducted by the member corporations are interdependent, the entire operations of the group become subject to tax in the state using this principle on the basis of a formula of apportionment. The unitary method concentrates on substance rather than form and treats all integrated business operations uniformly, whether they are conducted through foreign corporations, branches, or tax havens. This method eliminates deferral. It also avoids the difficulties of enforcement of the arm's-length direct system of taxation used by most states since source is not the only basis upon which the income attributable to a state may be measured.

A formula of apportionment is used to determine the amount of income generated by the entire operation that is properly attributable to the activities conducted within the taxing state. For instance, Galifornia uses the combined report, which is a consolidated return of the corporate group's world-wide income in order to determine the proportionate parts of the total income of the corporate group upon

2 See Uniform Division of Income for Tax Purposes Act, 7A U.L.A. 331. For an up to date list, see West's Annotated California Codes, Revenue and Taxation Code, ss. 2300 I-28000 ( 1988 Cumulative Pocket Part, at I 72). 
which the individual members are taxable. ${ }^{3}$ The California unitary tax system is by far the most significant one in terms of economic impact on international business activities. The unitary tax concept is opposed to the separate accounting method or arm's-length method, which, although it purports to isolate portions of income received in various states, may fail to account for contributions to income resulting from functional integration, centralization of management, and economies of scale. Also it is difficult to establish fair arm's-length prices for goods transferred or basic international services rendered between controlled branches or subsidiaries of an enterprise.

The unitary method used in California involves the following steps:

First, it must be determined whether the operations of a corporate group conducted partly within and partly without the state of California are unitary. A business is not unitary unless interdependent basic operations are carried on to a substantial extent in different states by the branches or subsidiaries that comprise the controlled enterprises; there must be functional integration and economies of scale resulting in a flow of value among the various operations.

Second, it is necessary to apportion a certain amount of the total income that includes foreign source income to the state of California. This is done by using a three-factors formula: all business income of an integrated group of corporations is apportioned to the state of California by multiplying such income by a fraction, the numerator of which is the property factor, plus the payroll factor, plus the sales factor and the denominator of which is three." The factors are determined by dividing the average value of the corporate group's California property by the value of its world-wide property ${ }^{5}$ the total amount of its California payroll, by its world-wide payroll $;^{6}$ and the amount of its total California sales by its total world-wide sales. ${ }^{7}$

3 Uniform Division of Income for Tax Purposes Act, West's Annotated California Codes, ss. 25120-39 and Regulations promulgated thereunder. For a good analysis, see L. Steven Spears, "Application of the Unitary Business Concept to Diverse Business: Light at the End of the Tunnel or the Impossible Dream?" ( 1987 ), 18 Pac. L. J. I16r.

4 S. 25128.

5 S. 25129.

b S. $25^{1} 32$.

7 S. 25134 . 
total

in-state property + in-state payroll + in-state sales $\times$ corporate

\begin{tabular}{|c|c|c|c|}
\hline total property & total payroll & total sales & income \\
\hline
\end{tabular}

It does not matter whether the California operations do not generate net income under the separate accounting method. If the world-wide operations show a net profit, California will consider the entire operations and allocate a portion of such profit to the state. ${ }^{8}$

This unitary tax has been criticized on the grounds that:

- It results in a multiple tax burden, or double taxation, unless the tax paid is offset by a reduced tax elsewhere.

- It conflicts with internationally accepted standards of allocation and apportionment used by the United States federal government. ${ }^{9}$

- It is contrary to tax treaties and commerce treaties which oppose unitary taxation. Commerce treaties prohibit tax discrimination against business entities of the other contracting party and "no tax shall be imposed in excess of that reasonably allocable or apportionable to its territories." The treaty with France goes further, providing that the basis for taxation must be directly related to activities within the taxing jurisdiction. ${ }^{10}$ The Treaty with Japan ${ }^{11}$ prohibits tax treatment that is more burdensome to a foreign state entity than to a domestic entity. The fact that United States corporations doing business in Japan are not taxed by Japan on the basis of world-wide income shows that there is discrimination.

- It enables California to collect taxes if no profit or even if losses exist in that state, thus resulting in double taxation. ${ }^{12}$

8 See Mobil Oil Corp. v. Commissioners of Taxes of Vermont, roo S. Ct. 1223, 445 U.S. $425 ; 63$ L.Ed. 2 d $510(1980)$, where it was held that it is permissible for a state to include foreign source dividends in a multinational corporation's apportionable tax so long as there is a unitary relationship between the payor foreign corporation and the recipient domestic corporation.

9 That is, the arm's-length standard of allocation whereby is taxed only the income that would have resulted to the taxpayer corporation had it dealt with the other members of the group at arm's-length in the conduct of its business.

10 Convention with respect to taxes on income and property with exchange of notes, July 28, 1967, 7 19 U.N.T.S. 3 I and Protocols of 1970,1978 and 1984 : 23 U.S.T. 20, 30 U.S.T. 5 109.

11 Gonvention for Avoidance of Double Taxation, March 8, 1971, 23 U.S.T. 967 , T.I.A.S. No. 7365 .

12 See argument of Plaintiff-Appellant in Shell Petroleum N.V. v. Graves et al., 709 F. 2d 593 (9th Cir., 1983) certiorari den., 104 S. Ct. 537, 464 U.S. 1012 , 78 L.Ed. $2 d 717$ ( 1983$)$. 
- Distortions result, since California wages are much higher than elsewhere in the world. Thus the payroll factor over-allocates world-wide income to California.

- Property costs are substantially higher in California than elsewhere in the world, again over-allocating world-wide income to California.

- The sales factor also over-allocates world-wide income as it does not take into account the relationship between profits and sales.

- California allocates world-wide profits without adjustments for other demonstrable differences. For instance, profits in developing states may be higher in relation to cost to reflect greater increased risks of expropriation, currency exchange limitations, tax holidays, and other factors. The result may be to allocate part of this risk profit (which is really a contingency reserve) to California.

- California allocates world-wide income even when such income includes substantial profits in foreign states that are blocked and that would not be subject to United States federal tax law until unblocked.

From a United States constitutional law point of view, a state cannot promote taxation that discriminates against interstate commerce. When foreign commerce is involved, state taxes must not create a substantial risk of multiple taxation on the international level or interfere with the federal regulation of foreign commercial relations. ${ }^{13}$ Thus, the unitary method of taxation by interfering with the power of the federal government to conduct foreign relations violates the Foreign Commerce Clause and the Supremacy Clause. ${ }^{14}$ Furthermore, due process precludes a state from taxing value earned outside its borders unless there is a minimal connection or nexus between the interstate activities and the taxing state and a rational relationship between the income attributed to the state and the intrastate value of the enterprise. ${ }^{15}$ In addition, the out-of-state activities of the unitary business must be related in some concrete way to the intrastate activi-

13 See Foreign Commerce Clause, U.S. Constitution, Art. I, s. 8, cl. 3. The power to regulate foreign commerce is reserved exclusively to the United States.

14 Since the Federal Executive possesses the sole and exclusive authority to conduct and control foreign affairs between the United States and foreign nations, state statutes that conflict with the constitutional exercise by the United States of its authority to conduct and control the foreign relations of the United States are void under the Supremacy Clause.

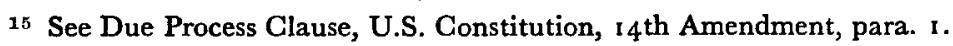


ties. The Foreign Commerce clause of the United States Constitution was intended to eliminate double taxation in interstate and foreign commerce.

The Supreme Court of the United States has held that apportionment of the income of corporations engaged in the conduct of business, both within and without the taxing state, is constitutionally permissible provided that multiple tax burdens do not result or produce arbitrary or unreasonable results. On the other hand, it is unconstitutional for a state to tax corporate profits earned elsewhere, but a state may use a formula to determine what is properly attributable to activities within its borders.

In Japan Line, Ltd. v. County of Los Angeles ${ }^{16}$ the United States Supreme Court held invalid under the Commerce Clause an ad valorem tax imposed by California on property found in the state on a given date, in this case containers belonging to a foreign shipping company, and used exclusively in international trade. The court was of the opinion that the California tax prevented the United States from speaking with one voice in international trade and subjected the containers to multiple taxation.

On the other hand, in Container Corporation of America v. Franchise Tax Board, ${ }^{17}$ the United States Supreme Court upheld the right of California to tax income earned outside the United States by a United States multinational group. The majority of the court was of the opinion that:

- The business must be unitary before taxation can disregard the boundaries of separate corporate entities and treat the commonly owned group as a single taxpayer. The prerequisite to a constitutionally acceptable finding of unitary business is a flow of value not a flow of goods.

- The unitary system must not result in excessive taxation of income earned outside the United States by comparison to income earned in the United States.

The Container Corporation had not demonstrated that income apportioned to California was out of all appropriate proportion to the business transacted in California. Furthermore, the risk of double taxation was the same as if the direct method of taxation had been used. The court came to the conclusion that the double taxation of

1844 I U.S. 434 ( 1979 ).

17 103 S. Ct. 2933, 463 U.S. 159, 77 L.Ed. 2d 545 (1983) reh. den. 104 S. Ct. 265,464 U.S. 909,78 L.Ed. 2 d 248 ( 1980 ). 
foreign income to which Container Corporation was subject did not rise to the level of a constitutional infirmity within the two tests set forth in the Japan Line decision: the need to permit the federal government to speak with a single voice in regulating foreign commerce and the need to avoid inevitable multiple taxation.

Multiple taxation is not necessarily excessive taxation. Here we are dealing with a United States-based group and state taxes were deductible for federal income tax purposes, which is not the case with respect to foreign income taxes (or where the United States corporation does not pay any federal income taxes).

With respect to foreign-based groups, there is the foreign policy effect to take into consideration, which was present in the Japan Line case, but not in the Container case. Will the court exclude unitary taxation in the case of foreign-based groups, a question expressly left open by the justices? As the court held, it is constitutionally not permissible for a state to tax instruments of foreign commerce in a manner that could be considered burdensome by the foreign state and that would invite retaliation against United States companies. Today, as a result of these cases, related domestic and foreign corporations may be treated as a unitary business to the extent that there is a sharing or an exchange of value throughout the multinational corporate group as evidenced by substantial mutual interdependence. In other words, in Container, the court held that the world-wide combined income of a domestic corporation and its foreign subsidiaries is subject to unitary apportionment, without contravening the due process and foreign commerce clauses, as long as the unitary business test has been properly applied and the apportionment formula is fair.

In Alcan Aluminum Ltd. v. Franchise Tax Board of Cal., ${ }^{18}$ a Canadian parent corporation challenged the use of California's unitary taxation method to determine its United States subsidiary's (Alcan Corp.) income tax liability. The court held that the parent lacked standing to challenge the use of that method since the parent's claim that California imposed a tax directly on its income was invalid and thus the parent had no distinct and palpable injury on which to base a claim of standing. The claim made by Alcan of direct taxation was invalid because California's tax is specifically structured to tax a corporation in proportion to the amount of business it does in California. The unitary tax is not a taxation of the parent on non-California business or income. Since the profits of a unitary business arise from ${ }^{18} 55^{8}$ F. Supp. 624 (S.D.N.Y., 1983). 
the operation of the business as a whole, it becomes misleading to characterize the income of the business as having a single identifiable source. Also, the unitary tax was imposed neither upon foreign commerce, nor upon Alcan itself. ${ }^{19}$

In order to remain within the permissible limits of international law, it would be better to apply the world-wide combined reporting under the unitary tax system to foreign subsidiaries of United States parent corporations only and to exempt from it local subsidiaries of foreign parents, especially where neither the foreign parents nor their subsidiaries are doing business in the unitary state. Another possibility called the "water's edge alternative" would be to limit state unitary taxation to domestic United States operations. The state would base its apportionment calculations on United States income as reported by the corporation in its federal return. This is calculated by the arm's-length method and therefore consistent with international practice and federal policy. Double taxation is avoided by international negotiation concluded by the federal government. California, for instance, would not concern itself with the details of the international allocation, but could apportion the American income using its threefactors formula. In 1986 several of the states that had adopted the unitary tax formula considered abandoning it for fear of losing a major share of new foreign investment.

Australia, Belgium, Canada, Denmark, France, the Federal Republic of Germany, the United Kingdom, Greece, Ireland, Italy, Japan, Luxembourg, The Netherlands, and Switzerland have objected to the unitary method of taxation on the ground that it constitutes "a serious obstacle to further development of trade and investment relationships." ${ }^{20}$ Also, in July 1985 , the Parliament of the United Kingdom passed legislation retaliating against United States corporations operating in unitary tax states. ${ }^{21}$ The legislation denies parent corpor-

19 See also EMI, Ltd. v. Bennett, 560 F.Supp. 134 (D.C. 1982), aff'd $73^{8}$ F. 2 d 994 ( 9 th Cir., 1984) certiorari den., 464 U.S. 1073, 83 L. Ed. $2 d 508$ (1984); Alcan Aluminum Lid. v. Department of Revenue of State of Oregon, 724 F. 2d 1294 (7th Cir., 1984); Shell Petroleum N.V. v. Graves, supra, note 12. And Brief as amicus curiae of the United States in Alcan Aluminum Ltd. v. Franchise Tax Board of Cal. and Imperial Chemical Industries v. Franchise Tax Board of Cal., reported in (1986) 25 Int'l Leg. Mat. 683. Also Alcan Aluminum, Ltd. v. Department of Revenue of State of Oregon, 724 F. 2d 1294 ( 7 th Cir., 1984).

20 See ( 1986 ), 25 Int'l Leg. Mat. 705.

21 Finance Act, 1985 , c. 54, s. 54 ( 1986 ), 25 Int'l Leg. Mat. 734. This section is to take effect after an order has been before the House of Commons and approved by a resolution. 
ations doing business in such states tax credits on the taxes they pay to the United Kingdom on account of dividends paid in England by their subsidiaries and imposes substantial penalties on them. These credits reflect the income taxes the United Kingdom subsidiaries pay with respect to the income they distribute as dividends.

Proposed federal legislation in the United States would prohibit any state of the United States from imposing an income tax on any taxpayer on a world-wide unitary basis. ${ }^{22}$

J.-G. CASTEL

Osgoode Hall Law School York University, Toronto

22 See Draft Legislation preventing Unitary Taxation by States ( 1985 ). ( 1986 ), 25 Int'l Leg. Mat. 739 et seq., Dec. 16, 1985, 99th Congress, ist Sess., Unitary Tax Repeal Act, Bill S. 1974 .

\section{Sommaire}

L'imposition unitaire aux États-Unis d'Amérique en matière d'impôts sur le revenu

L'auteur soutient que les États des Etats-Unis d'Amérique violent le droit international lorsqu'ils imposent les sociétés qui font affaires chez eux sur la base du revenu global du groupe de sociétés auxquelles elles appartiennent. Une formule spéciale permet d'attribuer un certain montant de ce revenu global à la société qui fait affaires dans un État qui a adopté ce système et qui en tiendra compte pour l'imposer. Le système de répartition des revenus imposables aboutit à une double imposition contraire aux traités signés par les États-Unis avec un grande nombre de pays y compris le Canada. Dans une certaine mesure, il est aussi contraire à la Constitution des Etats-Unis et aux règles coutumières du droit international se rapportant à la compétence législative des Etats. Sans aucun doute, le système unitaire constitue un obstacle aux investissements étrangers. 